\title{
THE ROLE OF MINDFUL PARENTING TO THE PARENTING STRESS IN MOTHERS WITH CHILDREN AT EARLY AGE
}

\author{
Dewi Kumalasari, Endang Fourianalistyawati \\ Faculty of Psychology YARSI University \\ J1. Letjend Suprapto, Cempaka Putih, Jakarta Pusat 10510 \\ dewi.kumalasari@yarsi.ac.id
}

\begin{abstract}
Parenting is an important process, and the processes in each phase are challenging, particularly during the phase of early childhood. The challenges in parenting could trigger parenting stress. The ability to give full attention to the conducted parenting process can help parents in coping the parental stress. The process of giving full attention to parenting activities is known as the mindful parenting concept. This study aims to determine the role of mindful parenting to parenting stress of mothers with a child at an early age. This study used a quantitative method. A Mindfulness in Parenting Questionnaire (28 items, $\alpha=.915)$ and Parental Stress Scale (18 items, $\alpha=.705)$ were given to the respondents. The data was collected from 281 respondents (ages 21-54 years, $M=32.75, S D=5$ ), which was selected through incidental sampling methods. Based on the regression analysis, the results show that mindful parenting has a significant contribution to the low parenting stress level in mothers with child at early age $\left(R=-.260, R^{2}=.068, \beta=-0.119, F(1,280)=20.153, p<0.01\right)$. This result suggests that mindful parenting skills can be an alternative way to reduce parental stress on mothers with a child in early childhood.
\end{abstract}

Keywords: early childhood; mindful parenting; parenting; parenting stress

\begin{abstract}
Abstrak
Pengasuhan merupakan proses yang penting dan selalu memiliki tantangan dalam setiap fasenya. Salah satu fase yang menantang adalah pada usia dini (early childhood). Tantangan pengasuhan ini dapat memicu munculnya stres pengasuhan. Kemampuan untuk memberikan perhatian penuh terhadap proses pengasuhan yang sedang dijalani dapat membantu orangtua dalam mengelola stres pengasuhan. Proses memberikan perhatian penuh terhadap kegiatan pengasuhan dikenal dengan konsep mindful parenting. Penelitian ini bertujuan untuk melihat peran mindful parenting terhadap stres pengasuhan pada ibu yang memiliki anak usia usia dini. Penelitian ini menggunakan pendekatan kuantitatif dengan instrumen Mindfulness in Parenting Questionnaire (28 item, $\alpha=$ $0,915)$ dan Parental Stress Scale (18 item, $\alpha=0,705)$. Data yang terkumpul berasal dari 281 responden (usia 2154 tahun, $M=32,75, S D=5)$ yang dipilih melalui metode sampling insidental. Berdasarkan analisis regresi, didapatkan hasil bahwa mindful parenting memiliki kontribusi yang signifikan terhadap rendahnya stres pengasuhan pada ibu yang memiliki anak usia dini $\left(R=-0,260, R^{2}=0,068, \beta=-0,119, F(1,280)=20,153, p<0.01\right)$. Hal ini mengindikasikan bahwa peningkatan keterampilan mindful parenting dapat menjadi salah satu alternatif untuk menurunkan stres pengasuhan pada ibu.
\end{abstract}

Kata kunci: anak usia dini; mindful parenting; pengasuhan; stres pengasuhan

\section{INTRODUCTION}

Parenting is a crucial element in shaping children's welfare (Child and Youth Studies Group, 2010). Good quality of parenting brings children to feel valuable, prosperous, have social competence and social values, and resilient. Parenting experienced by children will have a significant impact on child development.
Parenting is an essential and also challenging process. Concerning child welfare, one of the most challenging phases of parenting in the early childhood phase. According to the United Nations Committee on the Rights of the Child (in the Child and Youth Studies Group, 2010), the period of early childhood is a period in which parental responsibilities are at the broadest and most intensive points 
related to all aspects of child welfare. Child welfare involves survival, health, physical and emotional security, standards of care, opportunities to learn and play, and freedom of expression. Thus, it can be concluded that the responsibility for parenting in the early age phase is significant because it relates to the many aspects of child welfare.

However, several studies have found that early childhood parenting activities can trigger parental stress. Crnic, Gaze \& Hoffman (2005) found that parents with a child at an early age often feel the daily hassles during their parenting, and experience cumulative stress always. Furthermore, in this phase, a child already has his/ her thoughts and desires. Unfortunately, they still do not understand what behaviors are socially accepted (Papalia, Olds \& Feldman, 2004). Therefore, the child still needs intensive supervision from their parents. The child's behavior at an early age can trigger parenting stress. The statement above is in line with the findings of Williford, Calkins, \& Keane (2007). They found that parenting stress increases along with increased behavioral problems at an early age.

Parenting stress is defined as a stress condition that arises as a response to the demands of parental roles (Deater \& Deckard, in Cronin, Becher, Christians, Maher, \& Dibb, 2015). Parenting stress is the level of stress experienced in carrying out parental roles (Hoekstra-Webers et al. in Zarina et al., 2012). According to Berry and Jones (1995), there are two components of parenting stress, namely the pleasure and strain components. The pleasure component is related to the achievements obtained in carrying out parental roles, such as happiness and affection (Zelman \& Ferro, 2018). When the parents sense the pleasure component greatly, they will experience low parenting stress. The strains component is related to the absence of resources when parents implement their parental roles, such as time, energy, selfesteem, or control (Zelman \& Ferro, 2018). In case parents sense the strains abundantly, parents experience high parenting stress.

Although parenting stress is inevitable, particularly when parents feel unsure about meeting the demands of parenting, parents could manage their parenting stress. Untreated parenting stress can affect the quality of parenting behavior, which can also impact the adaptability, emotional, behavioral, and physical development of children (Deater-Deckard in Chung et al., 2013). Studies conducted by Cappa, Begle, Conger, Dumas, and Conger (2011) found that parenting stress is strongly and significantly related to the social competence of early childhood. Similar findings were also found from the research results of Estes et al. (2009). They discovered that behavioral problems in children are related to parental stress experienced by mothers. That finding is also reinforced by the findings of Neece, Green, and Baker (2012). They found that behavioral problems in children and parental stress are two significantly related variables.

In order to manage parental stress properly, parents need to have the ability to give full attention to the parenting process that is being performed (Siegel \& Hartzell in Bogles, Lehtonen, \& Restifo, 2010). The process of giving full attention to parenting activities is known as the mindful parenting concept. Mindful parenting, followed by a selfevaluation regarding parenting style, can improve the ability to manage parenting stress (Lestari, 2012).

Mindful parenting is an activity of giving attention to the child, and the parenting process with purposes focused on the present and avoided judgment (Kabat-Zinn \& KabatZinn in McCaffrey, Reitman and Black, 2017). In recent years, many researchers have been interested in researching the concepts of mindful parenting and stressful parenting in the context of caring for children with special needs. All these research afford empirical evidence showing the positive impact of mindful parenting, which can reduce the level 
of parental stress on parents with special needs children. Research Van Der Oord, Bogels, and Peijnenburg (2012) found that mindful parenting can reduce the level of parental stress in parents with ADHD children. Similar results were obtained from Neece's (2014) study, which found that mindful parenting successfully reduced stress and depression levels of parents with children with developmental delay children. Besides, mindful parenting also contributes to positive parenting practices (Han et al., 2019) and the establishment of secure attachments (Pepping, O'Donovan, \& Davis, 2014).

In order to enhance the finding of previous studies about mindful parenting and parenting stress on parents with special needs children, this study is conducted to investigate the contribution of mindful parenting on reducing the level of parenting stress in mothers with children in early age phase (ages 3-6 year). This study focuses on mothers' stress because commonly, mothers are more involved in parenting and more vulnerable to parenting stress. Some previous studies mention that mothers experience more parenting stress than fathers (Jackson, Ternedest, Magnuson, \& Schollin, in Widarsson et al., 2012). The result of study above is in line with the statement of Barnett and Baruch (in Berry \& Jones, 1995) that the role of parenthood is a significant source of stress for women because of their responsibilities and obligations as parents who are more involved in care. That result is in accordance also with the research of Kim and Choi (2015), founding that mothers experience more parental stress than fathers related to their primary role in parenting. The hypothesis proposed in this study is that Mindful parenting has a significant contribution to parenting stress, especially in mothers with early childhood children.

\section{METHOD}

\section{Research Design}

This study is quantitative research. In quantitative research, the data will be statistically analyzed (Seniati, Yulianto, and Setiadi (2015). A quantitative approach is used to test the hypotheses. This research is classified as a cross-sectional study because the data were collected at one time.

\section{Research Subject}

In this study, subjects were 281 mothers (ages 21-54 years, $\mathrm{M}=32.75, \mathrm{SD}=5$ ), and they have early age children. A total of 141 participants $(50.2 \%)$ have male children, while the rest $(49.8 \%)$ have female children. As many as 86 participants $(30.6 \%)$ have three years old children, 73 participants (26\%) have children aged four years, 67 participants $(23.8 \%)$ have children aged five years, and 55 participants $(19.6 \%)$ have a 6years. Participants came from diverse educational backgrounds, from elementary school to master. As many as $32.7 \%$ of the participant has a high school, and $35.6 \%$ has bachelor educational background.

\section{Research Instruments}

This study used Mindfulness in Parenting Questionnaire (MIPQ). MIPQ (28 items, $\alpha=$ $0.915)$ is a self-report questionnaire developed by McCaffrey, Reitman and Black (2017), and it measures mindful parenting. Mindful parenting is composed of two dimensions, namely the child-centred dimension and dimension focusing on parenting-process. McCaffrey, Reitman and Black (2017) name the dimension focusing on the parenting process as a mindful discipline. This dimension includes nonreactivity and parental awareness. Meanwhile, the child-centred dimension is called "being in the moment with the child". This dimension reflects the child's centred attention, empathic understanding and acceptance of the child.

There are 4 respond choices namely rarely (1), sometimes (2), often (3) and almost always (4). An example of an item in the mindful discipline dimension is: "In the past two weeks, how often have you taken a moment to think before punishing your child". While the example of items in the 
dimension of being in the moment with the child is: "In the past two weeks, how often have you been having fun and acting funny with your child". The higher the MIPQ score is, means the higher the mindful parenting of the subject.

Besides MIPQ, this study also used the Parental Stress Scale (PSS). PSS (18 items, $\alpha$ $=0.705)$ is a self-report questionnaire developed by Berry and Jones (1995) to measure parenting stress with five response choices, namely strongly disagree (1), disagree (2), neutral (3), agree (4) and strongly agree (5). Some item examples are: "I am happy with my role as a parent", "the main source of pressure in my life is my child (children)". The higher the PSS score is, the higher the parenting stress experienced by the subject. The MIPQ and PSS scales have been used in previous studies of Gani \& Kumalasari (2019) and Amalia \& Kumalasari (2019).

\section{Data Analysis}

In order to make a decision about the research hypothesis, the data was analyzed with simple regression test. Before conducting a simple regression test, the assumption test was measured to ensure that a simple regression test can be applied appropriately. The assumptions test included normality and linearity test.

\section{RESULTS AND DISCUSSION}

Based on the correlation test, the Pearson product-moment technique, it was found that mindful parenting has a significant negative correlation with parental stress, with a small degree of relationship $(\mathrm{r}=-0.260, \mathrm{p}<0.00)$. In other words, the more mother implements mindful parenting, the lower the stress of parenting she has.

In order to investigate the contribution of mindful parenting on parental stress, the data were also analyzed using simple regression test. The results of the regression model are $\mathrm{F}$ $(1,280)=20,153$ and $p<.05$, it indicates that mindful parenting has a significant contribution to parental stress, with $\mathrm{R} 2$ of $0.068(6.8 \%)$. Each one increase score in mindful parenting will be followed by a decrease score in parental stress with the amount of $0.0119(\beta=-0.119, \mathrm{p}<0.001)$.

The results of this study are in line with the statement of Lazarus and Folkman (in Duncan, Coatsworth, \& Greenberg, 2009) asserting that mindful parenting is a potential psychological resource in the process of managing stress. This result is also strengthened by previous research conducted by Beer et al., founding that mindful parenting has a contribution in reducing parenting stress (Beer, Ward, \& Moar, 2013; Bögels, Hellemans, van Deursen, Römer, \& van der Meulen, 2014; Bögels \& Restifo, 2014; Gouveia, Canavarro, \& Moreira, in Medeiros, Gouveia, Canavarro, \& Moreira, 2016). Corthorn \& Milicic (2016) also found that mindful parenting can predict low parental stress.

Duncan (in McCaffrey, Reitman and Black, 2017) states that mindful parenting is expected to reduce reactivity in parenting, increase patience, parenting flexibility, consistency and carry out parenting activities following predetermined values and parenting goals. Furthermore, mindful parenting is believed to improve parent-child relationships by developing trust and sharing emotions, reducing parental stress and increasing children's well-being (Duncan et al. in McCaffrey, Reitman and Black, 2017). The research result reinforces the previous statement by Bogels et al. (2013). Bogle found that mindful parenting was proven to reduce parental stress in parents having problems with parenting.

Mindful parenting is the ability to give attention to children and the purposeful parenting process, focused on the present and without judgment (Kabat-Zinn \& Kabat-Zinn in McCaffrey, Reitman, \& Black, 2017). The ability to pay attention to the parenting process is a dimension of mindful discipline, 
while the ability to pay attention to children is a dimension of being in the moment with the child. Both dimensions are the dimensions that construct mindful parenting.

Mindful discipline reflects the ability of parents to apply non-reactive parenting, the parent with awareness in parenting and perform activities focusing on parenting purposes (McCaffrey, Reitman \& Black, 2017). Concerning parenting stress, Bögels, Hellemans, van Deursen, Römer, \& van der Meulen (2013) explain that under stress situation, parental knowledge and skill can be forgotten and will be recalled when parents learn to realize their feelings and take breaks in a depressed condition. Furthermore, parenting stress is related to the processes that occur in the brain.

Furthermore, Bögels et al. (2013) explain that in a stressful parenting situation, parents may respond by fighting on children, running away from the condition (flight) or just staying quiet (freeze). When an individual is in a stressful condition, quick response is elicited through the shortest route in the brain, which is located in the brain stem. The brain stem helps to regulate the alertness and bodily functions such as breathing and heart rate. The brain stem is also responsible for the fight-flight-freeze response, combined with the limbic area. This short route does not pass through the pre-frontal cortex, which is an essential part of paying attention. Thus, it appears that mindful discipline provides an opportunity for parents to take a break before responding to things that trigger parenting stress in order to display responses that are not reactive and in line with the goals of caregiving.

Being in the moment with the child is reflecting attention that is centred on the present moment, empathic understanding about children and acceptance of children (McCaffrey, Reitman \& Black, 2017). Lehr, Wecksell, Nahum, Neuhaus, Teel, Linares \& Diaz (2016) found that children's characteristics are related to parental stress. In caring for young children, parents often confronted with less adaptive child behaviour, for example, temper tantrums. Tantrum temper is an explosion of emotions that is very strong and accompanied by anger, aggressive attacks, screaming, stomping feet and hands on the floor or ground (Chaplin, 2011).

In the research of Kim and Choi (2015), it was found that the child's temperament was one of the stress sources for the mother because mothers tended to perceive that the child's temperament was a pressure. In order to change the mother perception into a more positive perception about child's temperament, parents need to apply the dimension of being in the moment with the child by giving full attention to the child's current condition and empathic understanding and accept the child. For example, when children show temper tantrums, instead of blaming the child's temper, parents can try to understand the reason for their behaviour. So that they can think of alternative solutions for children. Through the dimension of being in the moment with the child, parents can provide full and focused attention to children and help the children to control their negative emotion.

Although it was found that mindful parenting contributes to low parenting stress, the results show that the contribution was only $6.8 \%$. The low contribution is also the reason for the poor correlation between mindful parenting and parenting stress $(r=-0,260, p<0.00)$. The resulting study is potential because the mindful parenting measured in this study is in the form of trait, not a state. Trait mindfulness is a condition of an innate trait mindfulness, whereas state mindfulness is a condition of mindfulness obtained from the mediation results (Baer, Smith, Hopkins, Krietemeyer, \& Toney in Kiken, Garland, Bluth, Palsson, \& Gaylord, 2015). In previous studies, the type of mindfulness, used in the studies that were mindfulness in state conditions. It means that participants were first skilled with mindfulness training so that the participants 
were skilful on mindfulness parenting and they were on the states of mindfulness (Van der Oord, Bögels \& Peijnenburg, 2012; Rodriguez-Jenkins \& Marchenko, 2014; Neece, 2014 ). In other words, mindfulness in the form of trait needs to be activated through meditation training, so that state of mindfulness can contribute significantly to the parenting stress.

The findings of the study provide information for parents and significant others concerning parental empowerment, namely to promote the importance of applying mindful parenting. Mindful parenting has a negative correlation with parental stress. The promotion about applying mindful parenting can be conducted by giving the recommendation of mindful parenting in regular counselling and administrating a mindful parenting training for parents.

\section{CONCLUSION}

Based on the finding above, it can be concluded that mindful parenting has a significant role in the low level of parenting stress.

\section{ACKNOWLEDGMENT}

The researcher would like to thank YARSI University for the full funding for this research.

\section{REFERENCES}

Amalia, P. M., \& Kumalasari, D. (2019). Openness to Experience, conscientiousness, extraversion, agreeableness, neuroticism: Manakah yang terkait dengan mindful parenting?. Intuisi, 11(2), 158-167.

Berry, JD, \& Jones, W,H, (1995) The Parental Stress Scale : Initial psychometric evidence. Journal of Social and Personal Relationships, 12, $463-472$.
Bögels, S. M., Lehtonen, A., \& Restifo, K. (2010). Mindful parenting in mental health care. Mindfulness, 1(2), 107-120.

Bögels, S. M., Hellemans, J., van Deursen, S., Römer, M., \& van der Meulen, R. (2013). Mindful parenting in mental health care: effects on parental and child psychopathology, parental stress, parenting, coparenting, and marital functioning. Mindfulness, 5(5), 536551.

Cappa, K.A., Begle, A.M., Conger, J.C., Dumas, J.E., \& Conger, A.J. (2011) Bidirectional Relationships Between Parenting Stress and Child Coping Competence: Findings From the Pace Study. J Child Fam Stud, 20, 334-342. doi: $\underline{10.1007 / \mathrm{s} 10826-010-9397-0}$

Chaplin, J.P. (2011). Kamus Lengkap Psikologi (Terjemahan). Jakarta: Rajawali Pers.

Child and Youth Studies Group. (2010). Supporting Parenting. Netherlands: The Open University

Chung, K.M., Ebesutani, C., Bang, H. M., Kim, J., Chorpita, B. F., Weisz, J. R.,Suh, D., \& Byun, H. (2013). Parenting stress and child behavior problems among clinic-referred youth: cross-cultural differences across the us and korea. Child Psychiatry Human Development, 44, 460-468.

Corthorn, C., \& Milicic, N. (2016). Mindfulness and parenting: A correlational study of nonmeditating mothers of preschool children. Journal of Child and Family Studies, 25, 1672-1683. doi: 10.1007/s10826-015-0319z.

Cronin, S., Becher, E.H., Christians, K.S., Maher M., \& Dibb, S. (2015). Parents and stress: Understanding experiences, 
context and responses. University of Minnesotta: Children's Mental Health eReview.

Crnic, K.A., Gaze, C. and Hoffman, C. (2005). Cumulative parenting stress across the preschool period: Relations to maternal parenting and child behaviour at age 5. Infant and Child Development, 14, 117-132. doi:10.1002/icd.384

Duncan, L.G.,Coatsworth, J.D., \& Greenberg, M.T. (2009). A model of mindful parenting: Implications for parent-child relationship and prevention research. Clin Child Fam Psychol Rev, 12, 255-270. doi:10.1007/s10567-009-0046-3

Estes, A., Munson, J., Dawson, G., Koehler, E., Zhou, X.-H., \& Abbott, R. (2009). Parenting stress and psychological functioning among mothers of preschool children with autism and developmental delay. Autism, 13(4), 375-387. doi:10.1177/1362361309105658

Gani, I.A., \& Kumalasari, D. (2019). Be mindful, less stress: Studi tentang mindful parenting dan stres pengasuhan pada ibu dari anak usia middle childhood di Jakarta. Jurnal Psikologi, 15(2), 98-107. doi:10.24014/ jp.v14i2.7744

Han, Z. R., Ahemaitijiang, N., Yan, J., Hu, X., Parent, J., Dale, C., DiMarzio, K., dkk. (2019). Parent mindfulness, parenting, and child psychopathology in china. Mindfulness. doi:10.1007/s12671-019-01111-z

Kiken, L. G., Garland, E. L., Bluth, K., Palsson, O. S., \& Gaylord, S. A. (2015). From a state to a trait: Trajectories of state mindfulness in meditation during intervention predict changes in trait mindfulness. Personality and Individual differences, 81, 41-46.

Kim, K., \& Choi, J. (2015). Sources of Parenting stress for mothers and fathers of young children. Indian Journal of Science and Technology, 8(35). doi: 10.17485/ijst/2015/v8i35/85

Lestari, S. (2012). Psikologi keluarga : Penanaman nilai \& penanganan konflik dalam keluarga. Jakarta: Kencana Prenamedia Group.

Lehr, M., Wecksell, B., Nahum, L. et al. (2016). Parenting Stress, Child Characteristics, and Developmental Delay from Birth to Age Five in Teen Mother-Child Dyads. J Child Fam Stud 25,1035-1043. doi:10.1007/s10826$\underline{015-0282-8}$

McCaffrey, S., Reitman, D., \& Black, R. (2017). Mindfulness in parenting questionnaire (MIPQ): development and validation of a measure of mindful parenting. Mindfulness, 8(1), 232-246.

Medeiros, C., Gouveia, M. J., Canavarro, M. C. \& Moreira, H. (2016). The indirect effect mindful parenting of mothers and fathers on the child's perceived well-being through the child's attachment to parents. Mindfulness, 7(4), 916-927. doi:10.1007/s12671-0160530-z

Neece, C.L. (2014). Mindfulness-based stress reduction for parents of young children with developmental delays: implications for parental mental health and child behavior problems. $J$ Appl Res Intellect Disabil, 27(2), 174-86. doi: 10.1111/jar.12064

Neece, C. L., Green, S.A., \& Baker, B.L. (2012). Parenting Stress and Child Behavior Problems: A Transactional Relationship Across Time. Am $J$ 
Intellect Dev Disabil, 117(1), 48-66. doi:10.1352/1944-7558-117.1.48

Papalia, D.E., Olds, S.W., \& Feldman, R.D. (2004). Human Development. New York: McGraw-Hill.

Pepping, A. C., O’Donovan, A., \& Davis, P. J. (2014). The differential relationship between mindfulness and attachment in experienced and inexperienced meditators. Mindfulness, 5, 392-399. doi:10.1007/s12671- 012-0193-3

Rodriguez-Jenkins, J., \& Marcenko, M. O. (2014). Parenting stress among child welfare involved families: Differences by child placement. Child Youth Serv Rev, 1 (46), 19-27. doi:10.1016/j.childyouth.2014.07.024.

Seniati, L., Yulianto, A., \& Setiadi, B. N. (2015). Psikologi Eksperimen. Jakarta: PT. Indeks.
Van der Oord, S., Bögels, S.M. \& Peijnenburg, D. (2012) The Effectiveness of Mindfulness Training for Children with ADHD and Mindful Parenting for their Parents. Journal of Child and Family Studies, 21(139). doi:10.1007/s10826-011-9457-0

Williford, A. P., Calkins, S.D., \& Keane, S.P. (2007). Predicting change in parenting stress across early childhood: Child and maternal factors. Journal of Abnormal Child Psychology, 35, 251-263.

Zarina, A. L., Radhiyah, R., Hamidah, A., Zakaria, S. Z. S., \& Jamal, R. (2012). Parenting stress in childhood leukaemia. Medicine \& Health, 7(2), 73-83.

Zelman, J. J., \& Ferro, M. A. (2018). The parental stress scale: psychometric properties in families of children with chronic health conditions. Interdisciplinary Journal of Applied Family Studies, 1-13. 